\title{
機能性食品開発の展望 \\ A View of Functional Foods Development
}

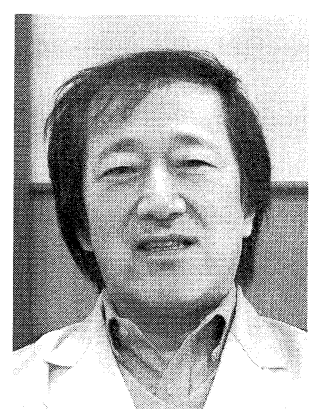

\author{
三島 敏 \\ アピ(株） 長良川リサーチセンター \\ T502-0071 岐阜市長良山先 692-3
}

Satoshi MISHIMA

Api Co., Nagaragawa Research Center,

692-3 Yamasaki, Nagara, Gifu-city, Gifu 502-0071, JAPAN

論文要旨：高齢者が加速度的に増加するわが国では，病気予防により健康寿命を延伸することが重要であ る。長い高齢期を元気な人生とするため，トクホを含む機能性食品への期待が高まっている。酵素技術や， 有用成分の創製あるいは製剤設計により食品機能を高めることは，種々の疾患に対しょり有効に働くと考え られる。

\begin{abstract}
It is important to extend healthy life time by preventing diseases under the greatelder population increasing in Japan. The functional foods are confident to meet the requirement making people vivid during their lives. Several ways enabling food functions more effective against diseases are proposed; by enzyme processing, preparation of bio-active ingredients, and drug formulation design.
\end{abstract}

Key words: functional foods, peptides, ACEI, prenylated compounds, microsphere

\section{1 はじめに}

高齢化の進行や生活習慣病罹患者およびその予備軍の 増加に伴い，健康寿命の延伸が課題となってきており， このためには治療以上に予防が重要であることは間違い ない。予防の基本は生活習慣の改善にあり，とくにその 中でも食事は大きな役割を担っている。わが国の食生活 の変化や環境，ストレス社会は多くの未病者を生み出し ている。こうした背景のもと, 食事や運動以外に特定保 健用食品をはじめとする機能性食品にも大きな期待がか けられている。

機能性食品とは, 食品の三次機能, すなわち生体調節 機能を持ち，かつその科学的根拠を有する食品である。 なかでも特定保健用食品（トクホ）は，臨床試験により 実証された科学的根拠の明らかな食品として, 厚生労働 大臣が認可するものである。したがって，消費者が安心 して直接あるいは医療分野で保健指導において利用され やすい。保健機能食品を除く他の機能性食品は, トクホ

連絡者：三島 敏

E-mail : mishima-satoshi@api3838.co.jp
と一部重複するが制度上は一般食品に分類されるため, 「機能」の表示は認められていない。機能性食品は, 卜 クホと比較すると概して臨床知見に乏しく，有用性・安 全性について懷疑的な見方をされる場合がある。しかし ながら，機能に関しては，用途が限定されているトクホ よりも多彩で，たとえば抗腫瘍，免疫，抗酸化，老化防 止等々消費者のニーズに応える機能性食品には多くの需 要があり，健康生活に果たす役割は大きい。

本稿では，機能性食品の開発として，トクホ製品の開 発，酵素を用いた機能性素材の創製，製剤化技術による 機能性の向上についての事例を紹介させていただく。

\section{2 機能性食品開発事例}

$2 \cdot 1$ ローヤルゼリーペプチドを関与成分とするトクホ 製品の開発

\section{$2 \cdot 1 \cdot 1$ 背景}

高血圧症は脳血管障害, 虚血性心疾患などさまざまな 疾患のリスク要因であり，とくに高齢者でその比率が高 く，今後さらに増加すると考えられている。高血圧症の 9 割を占める本態性高血圧の発症には，さまざまな原因 
が複雑に関与している。この中で，レニンーアンジオテ ンシン系およびアルドステロンは，生体内における血圧 の調節に重要な役割を果たしている。アンジオテンシン 変換酵素 $(\mathrm{ACE})$ は，アンジオテンシノーゲンより生成 するアンジオテンシン I をアンジオテンシン II に変換す る。このアンジオテンシン II は, 主に細動脈平滑筋を収 縮させて血圧を上昇させる血管収縮作用と, 副腎球状層 に作用してアルドステロンの合成と遊離を促進させるこ とによる昇圧活性を有する。ACE 阻害剤はアンジオテ ンシン II の産生を抑制し，アルドステロン量を減少させ るため，高血圧症の治療に広く用いられている ${ }^{1,2)} 。 し か$ しながら，薬物療法には少なからず副作用を伴い，また 医療費の負担も考慮した場合，正常高值血圧者や軽症高 血圧者については，食による生活習慣の改善こそが望ま れる。こうした背景のもと，近年，さまざまな食品由来 の夕ンパク質 ${ }^{3-5)}$ から ACE 活性阻害ペプチドが単離さ れ，高血圧を予防・改善する特定保健用食品が開発され ている。

ローヤルゼリー（RJ）は働き蜂の下咽頭腺から分泌さ れる乳白色のクリーム様物質であり，タンパク質，糖 質，脂質，アミノ酸，ビタミン，ミネラルを豊富に含ん でいる。RJ は滋養強壮や更年期障害，貧血の改善，お よび抗腫瘍作用，血流増加作用などさまざまな生理活性 を有し, 医薬品, 食品として広く利用されている。ここ では，RJ を酵素分解して得られるぺプチドを関与成分 とするトクホ製品の開発について紹介する。

\section{$2 \cdot 1 \cdot 2$ ACE 阻害ペプチドの同定}

ミツバチApis melliferaより得られた中国産生 RJを 各種プロテアーゼで処理し, 得られた RJペプチドの ACE 阻害活性を測定した。その結果, Bacillus subtilis 由来のプロテアーゼ処理で得られた RJペプチドが良好

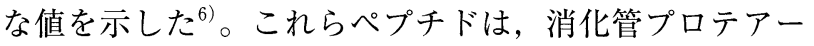

ゼであるペプシン，トリプシン，キモトリプシン等でさ らに処理しても，ACE 阻害活性の変化はほとんど認め られなかった。したがって，このぺプチドは経口摂取し ても消化管プロテアーゼによる消化を受けることなく， ACE 阻害活性を示すことが示唆された。

そこで，高血圧自然発症ラット（SHR）を用い収縮期 血圧（SBP）が $185 \mathrm{mmHg}$ 以上を示す雄性 SHR に, RJ および RJ ペプチドを 1 回 $5 \mathrm{mg} / \mathrm{kg}$ の投与量で 1 日 2 回，28 日間反復経口投与した。1 回目の投与前および 2 回目の投与後 $2 \mathrm{~h}$ 間の SBP を測定したところ, 対照群と 比較して，とくにRJペプチド群は低值を示した（Fig. 1) ${ }^{7)}$ 。

この RJ ペプチドから 6 種類の ACE 阻害活性を有す るペプチドを単離し，中でもIle-Tyr（IY）が最も強い 阻害活性（ $\mathrm{IC}_{50}=8 \mu \mathrm{g} / \mathrm{mL}$ ）を示し, Ile-Val-Tyr (IVY) $(18 \mu \mathrm{g} / \mathrm{mL}), \operatorname{Val}-\mathrm{Tyr}(\mathrm{VY})(20 \mu \mathrm{g} / \mathrm{mL})$ の順 であった ${ }^{8)}$ 。これら 3 種ペプチドIY, VY, IVYを単独 または混合して SHR に単回経口投与し投与前と投与 1 時間後の SBP 值を測定したところ，いずれにおいても 1 $\mathrm{mg} / \mathrm{kg}$ の投与量で SBP 值の顕著な低下が認められた

\section{$2 \cdot 1 \cdot 3$ 作用機序}

$\mathrm{RJ}$ ペプチド $2 \mathrm{~g} / \mathrm{kg}$ を単回経口投与し， $6 \mathrm{~h}$ 後に腹部 大動脈，心臓，肺，肝臓，腎臓および脳を摘出した。各 臓器可溶性画分の ACE 活性を測定したところ，対照群 と比較して, RJ ペプチド投与群の腹部大動脈, 肺にお いて ACE 活性の低下が認められた。一方，心臓，肝臓， 腎臓および脳においては ACE 活性の低下はみられな かった (Fig. 2) ${ }^{10)}$ 。

また，各蔵器の ACE 阻害ぺプチドを定量したところ， ACE 活性の低下がみられた腹部大動脈，肺および血漿 では，投与群において対照群よりも多量のIY，VY， IVYが検出された。一方，ACE 活性の低下がみられな
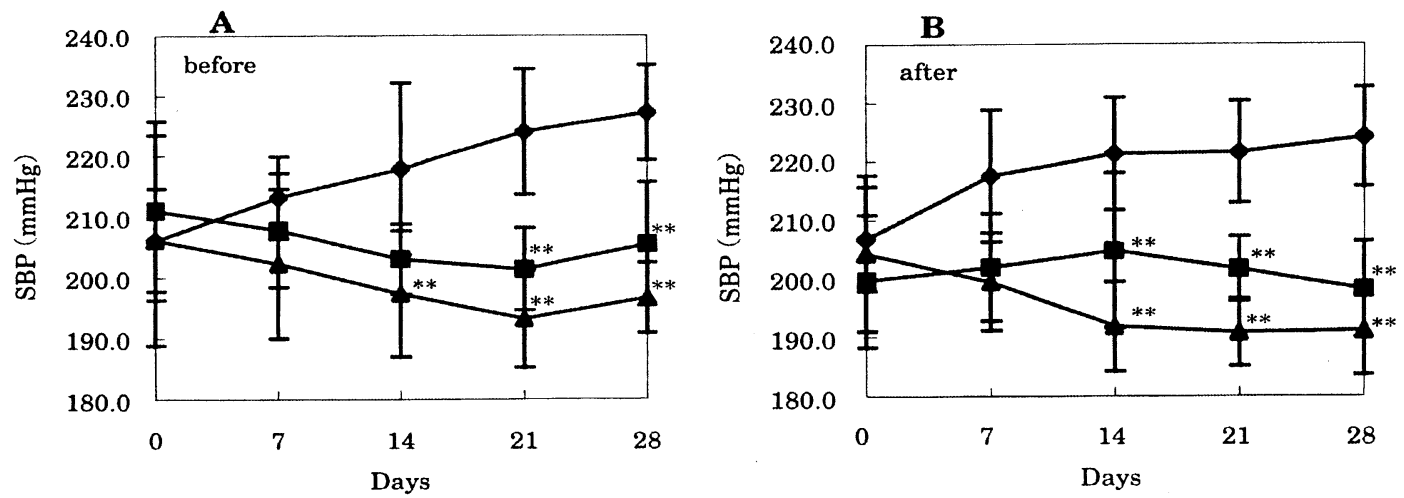

$\longrightarrow$ Cont. $(n=10) ; \rightarrow \operatorname{RJ}(n=10) ;-\operatorname{ProRJ}(n=6)$.

Fig. 1 SHRにおける RJ, RJペプチドの経口投与前(A)および投与 2 時間後(B)の収縮期血圧の推移 ** $\mathrm{p}<0.01$ vs. Control 

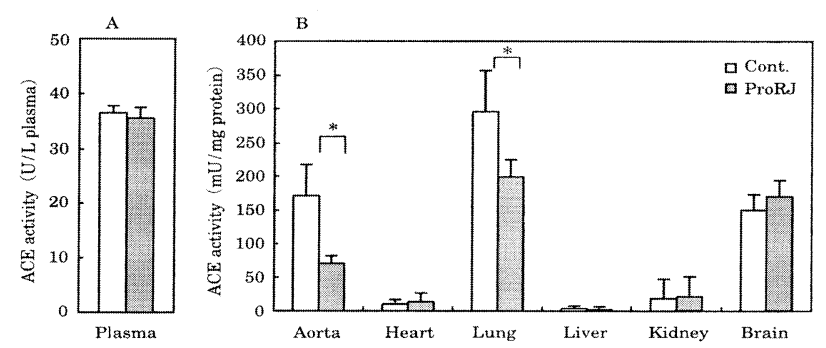

Fig. 2 RJ ペプチド投与 6 h 後の SHRの血漿(A)およ゙臓器 (B)の ACE 活性

$* \mathrm{p}<0.05$ vs. Control

かった臓器においては，これらぺプチドは検出されな かった。以上の結果から，RJペプチドが消化管から吸 収されて血中に移行し, 前記特定臓器において ACE 活 性を阻害することにより，血圧降下作用を発現すること が示唆された。

同時に，投与前後 $1 \sim 8 \mathrm{~h}$ 後に採血および SBP 值の測 定を行い, 投与後 $8 \mathrm{~h}$ まで血圧低下状態の持続を確認し た。また血漿アルドステロン量は, 投与後 $1 \mathrm{~h}$ で有意に 減少し，この状態が $4 \mathrm{~h}$ 後まで持続していた。したがっ て，RJペプチドはレニンーアンジオテンシンならびに アルドステロン系に作用して，血圧降下を誘導すること が示唆された。

\section{$2 \cdot 1 \cdot 4$ 非臨床（動物）安全性試験}

ラットを用いた単回経口投与毒性試験 $(4 \mathrm{~g} / \mathrm{kg})$ ，お よび 90 日間経口投与毒性試験（〜 $1.2 \mathrm{~g} / \mathrm{kg} ）$ では, RJ ペプチドによる異常はみられなかった。また, 哺乳類の 培養細胞を用いた染色体異常試験（～ $5 \mathrm{mg} / \mathrm{mL})$, およ び細菌を用いた復帰突然変異試験（〜 $5 \mathrm{mg} /$ plate）にお いても, RJペプチドはともに陰性を示し, その安全性 が確認された。

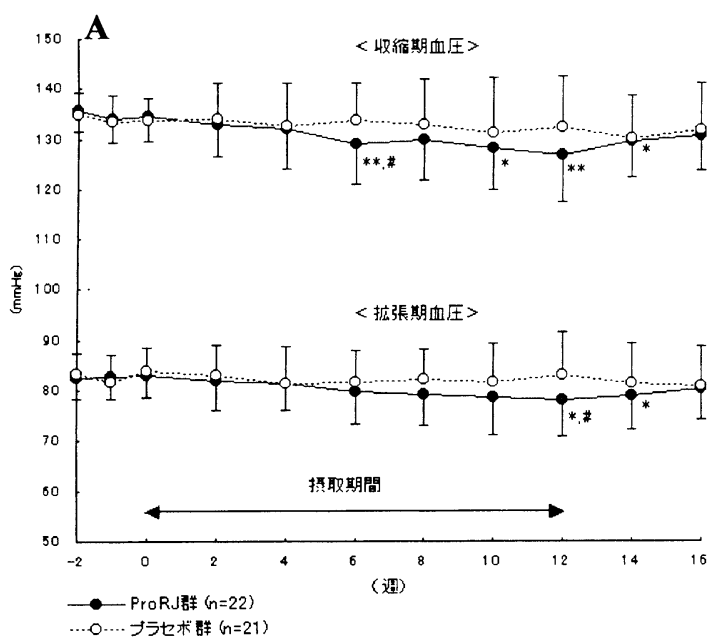

\section{$2 \cdot 1 \cdot 5$ 臨床試験}

RJ ペプチドを正常高值血圧者と軽症高血圧者に対し， プラセボを対照とした 2 重盲検試験を実施した。8 7 名 の被験者を RJ ペプチド 1200〜 7200 mg/日掑取群および プラセボ摂取群に分け, 試験飲料を 4 週間摂取させた。 その結果, RJ ペプチド $2400 \mathrm{mg} /$ 日摂取群または 7200 $\mathrm{mg} /$ 日摂取群で, 収縮期血圧は摂取 4 週間後に摂取前と 比較して有意な低值を示した。また拡張期血圧は 7200 $\mathrm{mg} /$ 日摂取群で摂取前と比較して有意な低值を示し た ${ }^{11)}$ 。

次に, 85 名の被験者を RJ ペプチド $2400 \mathrm{mg}$ /日摂取 群とプラセボ摂取群に分け, 試験飲料を 12 週間摂取さ せた長期試験を実施した。その結果，RJペプチド摂取 群では収縮期血圧および拡張期血圧ともに, 摂取 8 週間 後および 12 週間後にプラセボ群と比較して有為な低值 を示した (Fig. 3：図は層別解析の結果) ${ }^{12)}$ 。いずれの試 験および正常血圧者による過剩摂取試験（7200 mg/日× 8 週間）においても，有害事象は認められなかった。以 上より，RJペプチドは正常高值血圧者と軽症高血圧者 に対して適度な血圧降下作用を示し, 安全性の高い食品 であると判定した。

2006 年 8 月末，この RJペプチドを関与成分とする飲 料は，「血圧が高めの方に適した」特定保健用食品とし て認可された。

\section{$2 \cdot 2$ プレニル化合物の酵素的創製}

\section{$2 \cdot 2 \cdot 1$ 背景}

ブラジル産プロポリスに含まれる抗がん，抗菌活性物 質を探索したところ，桂皮酸誘導体であるバッカリン (3-プレニル-4-(2,3-ジヒドロキシシンナモイロキシ) 桂皮酸), ドルパニン（3-プレニル $\mathrm{p}$-クマル酸）が見出

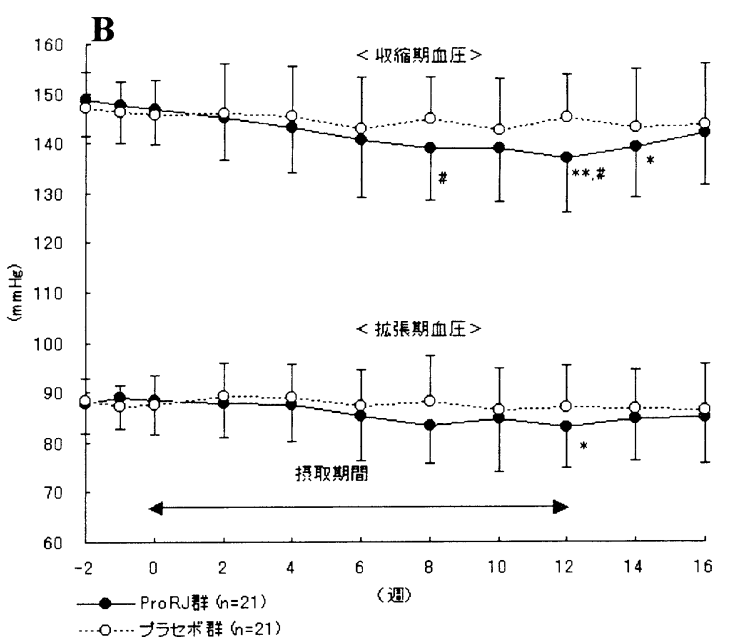

Fig. 3 正常高值血圧者(A)および軽症高血圧者(B)の血圧值の推移 プラセボ摂取群との比較; ${ }^{*} \mathrm{p}<0.05$ (t-test) 摂取直前との比較 $;{ }^{*} \mathrm{p}<0.05,{ }^{* *} \mathrm{p}<0.01$ (Bonferroni test) 
された。これらは各種癌細胞に対し，アポトーシス誘導 や増殖抑制作用を示した。また Sarcoma S-180 移植マ ウスにおいて，腫瘍重量の増加が有意に抑制された ${ }^{13)}$ 。 ブラジル産プロポリスに含まれるアルテピリンC（3,5ジプレニル-4-ヒドロキシ桂皮酸）もがん細胞の増殖を 抑制することがすでに報告されている ${ }^{14)}$ 。これら 3 種の 化合物はいずれも，プレニル基を持つフェニルプロパノ イド構造である。

プレニル化された芳香族化合物は植物に広く分布して おり，これらは植物の耐虫性や耐病性などの作用に寄与 している。プレニルフラボノイドには, 抗菌, 抗酸化, 抗腫瘍, 抗チロシナーゼ活性, エストロゲン活性等, さ まざまな生理活性を有するものが報告されている。この ようなプレニル芳香族化合物の生理活性は，プレニル基 を持たない母核化合物ではみられない場合もあり ${ }^{15,16)}$, その活性にプレニル基が重要であることが指摘されてい る。

ここでは，放線菌の芳香族基質プレニル基転移酵素を 利用し，プロポリスに含まれるフラボノイドやフェニル プロパノイドにプレニル基の導入した例，およびその反 応産物の機能性について紹介する。これらのうち, 食経 験ある化合物は強化食品として応用ができる。

\section{$2 \cdot 2 \cdot 2$ プレニルフラボノイドの創製}

プロポリスに含まれる主要なフラボノイドであるガラ ンギンおよびイソサクラネチンを基質とし, 放線菌由来 のプレニル基転移酵素（Orf 2, HypSc）を用いてプレニ ル基，ゲラニル基の導入を試みた。ガランギンをゲラニ ル基受容体，GPP を供与体とし，Orf 2 を添加して反応 させたところ，6-ゲラニルガランギンを得た。同様にイ ソサクラネチンをゲラニル基受容体とした場合には，6ゲラニルイソサクラネチンおよび 7-O-ゲラニルイソサ クラネチンを得た。また，ジメチルアリル基受容体， DMAPP を供与体とし，HypSc を用いて反応させたと ころ，6-プレニルイソサクラネチンを得た。

\section{$2 \cdot 2 \cdot 3$ プレニルフェニルプロパノイドの創製}

上記と同様に，プロポリスに含まれる主要なフェニル プロパノイドである $\mathrm{p}$-クマル酸掞よびカフェ酸を基質 とし，放線菌由来のプレニル基転移酵素（NovQ）を用 いてプレニル基の導入を試みた。 $\mathrm{p}$-クマル酸をプレニル 基受容体，DMAPP を供与体とし，NovQを添加し反応 させたところ，3-プレニル-p-クマル酸（ドルパニン） および 4-O-プレニル-p-クマル酸を得た。同様にカフェ 酸をプレニル基受容体とした場合には，3-O-プレニル カフェ酸，4-O-プレニルカフェ酸および 3-O, 4-O-ジプ レニルカフェ酸を得た。

\section{$2 \cdot 2 \cdot 4$ プレニル化合物の生理活性評価}

\section{$2 \cdot 2 \cdot 4 \cdot 1$ 細胞増殖試験}

ヒト胃癌細胞 Kato III およびヒト大腸がん細胞 SW 480 の各細胞を培養後，1 日後に試料を添加，2 日後に MTTアッセイにより生細胞数を測定した。その結果, プレニル基をもっていないガランギンおよびイソサクラ ネチンは, 特定の濃度で細胞増殖を促進することはあっ ても，増殖抑制活性はみられなかった。これに対し，プ

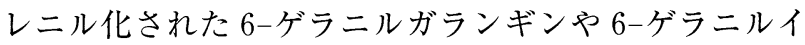
ソサクラネチンでは, 細胞増殖の抑制が認められた。ま た， $\mathrm{p}-ク マ ル$ 酸およびカフェ酸には，増殖抑制活性はみ られなかったが, これらのプレニル化物は, 細胞種によ り影響は異なるものの，がん細胞に対し概ね弱い増殖抑 制活性が認められた。

$2 \cdot 2 \cdot 4 \cdot 2$ MRSA に対する抗生剂との併用効果

作用機序の異なる 3 種類の抗生剤 Oxacillin, Tetracyclin, Chrolamphenicolの多剂耐性黄色ブドウ球菌 MRSA（ATCC 33591）増殖を阻止する最小濃度（MIC） を確認した。次に，感受性測定ブイヨンにて 2 種類の被 検物質を互いに濃度を変えて併用した培地に試験菌液を 接種し, 一晚培養後, 目視にて増殖判定を行った。抗生 剂と試料の組み合わせによる併用効果を判定するため, FIC index (fractional inhibiting concentration index,

Table 1 MRSA に対する抗生剂との併用効果

\begin{tabular}{|c|c|c|c|c|}
\hline & \multirow{2}{*}{$\begin{array}{c}\text { MRSA } \\
(\mathrm{MIC} u g / m L)\end{array}$} & \multicolumn{3}{|c|}{ 併用効果（FIC index） } \\
\hline & & オキサシリン & $\begin{array}{c}\text { テトラ } \\
\text { サイクリン }\end{array}$ & $\begin{array}{c}\text { クロラム } \\
\text { フェニコール }\end{array}$ \\
\hline $\mathrm{p}$-クマル酸 & 800 & 0.75 (相加) & 1 (相加) & 1 (相加） \\
\hline ドルパニン & 400 & 0.5 (相乗) & 0.5 (相乗) & 0.5 (相乗) \\
\hline 4-O-プレニル-p-クマル酸 & 400 & 0.25 (相乗) & 0.5 (相乗 $)$ & 0.38 (相乗 $)$ \\
\hline カフェ酸 & 1600 & 2 (無関係) & 2 (無関係) & 2（無関係） \\
\hline 3-O-プレニルカフェ酸 & 800 & 2 (無関係) & 2 (無関係) & 1 （相加） \\
\hline 4-O-プレニルカフェ酸 & 400 & 1 (相加) & 1 （相加） & 0.75 (相加） \\
\hline 3-O,4-O-ジプレニルカフェ酸 & 400 & 2 (無関係) & 0.75 (相加) & 0.38 (相乗 $)$ \\
\hline
\end{tabular}


併用時の抗生剂 $\mathrm{MIC} /$ 単独の抗生剂 $\mathrm{MIC}+$ 併用時の試料 $\mathrm{MIC} /$ 単独の試料 MIC）を求めた。FIC index が 0.5 以 下の場合には抗生剤と試料の相乗効果, また, 0.5 より 大きく 2 より小さい場合には相加効果と判定した。

その結果, $\mathrm{p}$-クマル酸やカフェ酸のプレニル化合物 は，抗生剤と併用することによって，例外はあるものの 概ね併用効果が認められた（Table 1)。とくに，ドルパ ニンや 4-O-プレニル-p-クマル酸では, 相乗的に抗菌活 性が上昇しており，MRSAに対して抗生剂の使用量を 顕著に減らすことができると考えられる。

またプレニル基をもっていないガランギンおよびイソ サクラネチンには, MRSAに対する抗菌活性はほとん ど認められないが，6-ゲラニルガランギンは MIC が $12.5 \mu \mathrm{g} / \mathrm{mL}$ とオキサシリンに相当する抗菌活性が認め られた。 $\mathrm{p}$ クマル酸, カフェ酸にも抗菌活性はほとんど 認められないが，これらのプレニル化合物には MRSA， MSSA（黄色ブドウ球菌), Bacillus（枯草菌）に対する 抗菌活性の上昇が認められた。

以上のように, 放線菌由来プレニルトランスフェラー ゼを用いてフラボノイドやフェニルプロパノイドなどに プレニル基を導入することができる。これにより，抗癌 性，抗菌性に優れた新規な化合物を創製できることが示 唆された。

\section{$2 \cdot 3$ 粘膜付着性製剤プロポリス SAM（Stomach Adsorp- tive Material)}

\section{$2 \cdot 3 \cdot 1$ 背景}

プロポリスには, 抗酸化, 抗炎症, 抗菌, 抗潰瘳, 抗 腫瘍，免疫賦活などのさまざまな生理活性が報告されて いる ${ }^{17)}$ 。関与する主な成分は, フラボノイド類, フェ ノール性有機酸類およびそのエステル等であり, その多 くは水に対する溶解度が小さく, 消化管内を容易に流下 してしまう。このため，これら有効成分の消化管内にお ける滞留時間が短く, 薬効が一時的にしか発揮されない 場合がある。また, その滞留時間の短さゆえに, 十分な バイオアベイラビリティが得られないことも問題であ る。このような問題点を解決する手段のひとつとして, プロポリス製剤に消化管粘膜付着性機能を持たせること が考えられる。そこで，粘膜付着性機能の付加によっ て, 吸収部位上部におけるプロポリス成分の滞留時間を 延長させ, 生体内で持続的に薬効を発揮し, かつ有効成 分の吸収率を向上させることを目的とした。

ここではキトサンを用いてプロポリスを含むマイクロ スフェアーを調製し，その消化管粘膜付着性および種々 の生理作用について検討した。

\section{$2 \cdot 3 \cdot 2$ マイクロスフェアーの調製方法}

油中溶媒拡散法によりプロポリス・キトサンマイクロ
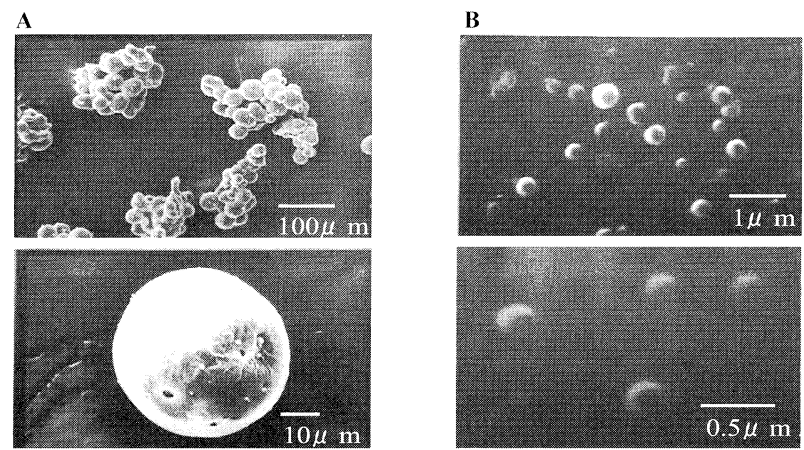

Fig. 4 油中溶媒拡散法で調製したSAM-M (A; 上, 200 倍, 下，1,500 倍）および水中溶媒拡散法で調製した SAM-N（B；上, 15,000 倍, 下, 35,000 倍）の SEM 写真

スフェアーを調製した。すなわち，界面活性剤（サンソ フトQ 81 F） にキトサン（FL 80）溶液を加えて攪拌し た後, EEP (プロポリスエタノールエキス) を加えて攪 拌し，キトサン・プロポリス溶液を調製した。次に，液 状油（トリエスターF 810）を加熱しながら攪拌し，そ こに前記キトサン・プロポリス溶液を添加した。これを 減圧下，加温下 $6 \mathrm{~h}$ 攪汼し，微粒子が油相に分散した賏 濁液を溶媒除去後乾燥して，プロポリス・キトサンマイ クロスフェアー（SAM-M）を得た（Fig. 4A）。また， 水中溶媒拡散法を用いてプロポリス・キトサンナノス フェアーを調製した。2 種の異なるキトサン（SK 2，FL 80）混合物に EEPを添加し，凍結乾燥してプロポリ ス・キトサンナノスフェアー（SAM-N）を得た（Fig. 4 B)。

\section{$2 \cdot 3 \cdot 3$ 胃粘膜付着性の評価}

Wistar 系雄性ラットを $24 \mathrm{~h}$ 絶食後, プロポリス従来 品およびプロポリス SAM-M, SAM-N を精製水に懸濁 し， $600 \mathrm{mg} / \mathrm{kg}$ ずつ経口投与した。投与 $4 \mathrm{~h}$ 後に胃を摘 出し, エタノール, $\mathrm{KCl}$ を含む溶液 $(\mathrm{pH} 1.9)$ で胃に付 着したプロポリスを抽出した。抽出液のプロポリス含量 を測定したところ, 従来品が $1 \mathrm{mg}$ 以下の残存量であっ たのに対し，プロポリス SAM-M, SAM-N では $2 \mathrm{mg}$ 以上の残存量を示した。これは，キトサンにプロポリス を内包することによって，粘膜付着性が付与されたため と考えられる。

\section{$2 \cdot 3 \cdot 4$ 吸収率の評価}

Wistar 系雄性ラットから小腸全体を摘出し，断片を 切り出して反転腸管を作成した。この反転腸管内にリン ガー液を注入し，雨端を木綿糸で結紮した。これをプロ ポリス従来品および SAM-M を含むリンガー液中に挿 入し，酸素を通気後，インキュベーションした。反転腸 管内の液を経時的にサンプリングして，各液中に含まれ る総フラボノイド量を測定した。その結果, 従来品では 30 min を経過した後, 吸収率は漸減するが, SAM-M で 
Table 2 投与 $1 \mathrm{~h}$ 後(A)および $3 \mathrm{~h}$ 後(B)における塩酸-エ夕 ノール潰瘍抑制活性

A

\begin{tabular}{|c|c|c|c|}
\hline $\begin{array}{c}\text { 投与 } 1 \text { 時間後 } \\
\text { (即時性) }\end{array}$ & $\mathrm{n}$ & $\begin{array}{c}\text { 潰瘍係数 }(\mathrm{mm}) \\
\text { 平均值 } \pm \text { S.D. }\end{array}$ & $\begin{array}{c}\text { 潰瘍抑制率 } \\
(\%)\end{array}$ \\
\hline Control & 5 & $28.8 \pm 9.0$ & - \\
\hline Propolis & 5 & $14.2 \pm 2.3$ & 50.7 \\
\hline SAM-M & 5 & $7.4 \pm 1.6^{*}$ & 74.3 \\
\hline SAM-N & 5 & $5.9 \pm 2.1^{*}$ & 79.6 \\
\hline
\end{tabular}

B

\begin{tabular}{|c|c|c|c|}
\hline $\begin{array}{c}\text { 投与 } 3 \text { 時間後 } \\
\text { (持続性) }\end{array}$ & $\mathrm{n}$ & $\begin{array}{c}\text { 潰瘍係数 }(\mathrm{mm}) \\
\text { 平均值 } \pm \text { S.D. }\end{array}$ & $\begin{array}{c}\text { 潰瘍抑制率 } \\
(\%)\end{array}$ \\
\hline Control & 7 & $57.7 \pm 11.7$ & - \\
\hline Propolis & 6 & $43.2 \pm 7.7$ & 25.1 \\
\hline SAM-M & 6 & $29.5 \pm 7.1^{*}$ & 48.9 \\
\hline SAM-N & 6 & $24.7 \pm 3.5^{*}$ & 57.2 \\
\hline \multicolumn{4}{|r}{${ }^{*}<0.05$ vs. control } \\
\hline
\end{tabular}

は $120 \mathrm{~min}$ の時点でも吸収率の低下は認められなかっ た。すなわち，プロポリス SAM では小腸におけるフラ ボノイドの吸収が長時間にわたって持続することが示唆 された。

\section{$2 \cdot 3 \cdot 5$ 胃潰瘍抑制活性の評価}

Wistar 系雄性ラットを $24 \mathrm{~h}$ 絶食後, プロポリス固形 分に換算して $30 \mathrm{mg} / \mathrm{kg}$ となるようにプロポリス従来品 および SAM-M，SAM-N をラットに経口投与した。投 与 $1 \mathrm{~h}$ 後 (即時性評価), または $3 \mathrm{~h}$ 後（持続性評価）に $\mathrm{HCl}$ ・エタノール溶液を, 経口投与して潰瘍を誘導した。 $1 \mathrm{~h}$ 後に胃を摘出して, 胃体部に生じた損傷の長さを測 定し, その総和を潰瘍係数とした。その結果, 試料投与 $1,3 \mathrm{~h}$ 後ともに, プロポリス SAM は従来品と比較して 高い潰瘍形成抑制率を示した（Table 2)。この効果は, プロポリス SAM が胃の粘膜に付着することにより, 滞 留時間が延長し，薬効が持続したためと考えられる。

以上のように，プロポリス SAM は消化管の粘膜に対 して高い付着性を有し, 滞留時間が延長することが示唆 された。これにより，プロポリス製剤に含まれる有効成 分のバイオアベイラビリティが向上し, その薬理作用を
持続的に発揮させることが可能になったと考えられる。

\section{3 終わりに}

科学的に機能を有する食品は, トクホや栄養機能食品 も含まれるが，そのレベルに達していなくても客観的に 評価に值するものであればそれも機能性食品と定義する ことができる。本稿では，一部の機能性向上法につき紹 介したが，これら加工物は機能のみならず安全性担保の 必要性はいうまでもない。さらに，摂取量においても十 分検討を重ね，最終的には臨床による評価が好ましい。

\section{文献}

1）尾前照雄ら, 治療, 71, 1101-4 (1998).

2) Cheung, B., Hong Kong Med. J., 8, 185-91 (2002).

3) Matsui, T., Matsufuji, H., Seki, E. et al., Biosci. Biotechnol. Biochem., 57, 922-5 (1993).

4) Yokoyama, K., Chiba, H. \& Yoshikawa, M., Biosci. Biotechnol. Biochem., 56, 1541-5(1992).

5) Yamamoto, N. \& Takano, T., Nahrung., 43, 159-64 (1999).

6）鈴木和道, 吉田千絵, 三島 敏ら, 日本食品科学工学 会誌, 50, 286-8 (2003).

7）徳永勝彦, 鈴木和道, 三島 敏ら, 日本食品科学工学 会誌, 50, 457-62 (2003).

8）丸山広恵, 德永勝彦, 三島 敏ら, 日本食品科学工学 会誌, 50, 310-5 (2003).

9) Tokunaga, K.H., Yoshida, C., Suzuki, K.M. et al., Biol Pharm Bull., 27, 189-92 (2004).

10）徳永勝彦, 鈴木和道, 三島 敏ら, 日本食品科学工学 会誌, 51, 34-7 (2004).

11）梶本修身, 丸山広恵, 三島 敏ら, 健康 - 栄養食品研 究, 7, 53-71 (2004).

12）梶本修身，丸山広恵，三島 敏ら, Health Sci., 21, 229-45 (2005)

13) Mishima, S., Ono, Y., Araki, Y. et al., Biol. Pharm. Bull., 28, 1025-30 (2005).

14) Kimoto, T., Arai, S., Kohguchi, M. et al., Cancer Detect. Prev., 22, 506-15 (1998).

15) Wang, B.H., Ternai, B. \& Polya, G., Phytochem., 44, 787-96 (1997).

16) Murakami, A., Gao, G., Omura, M. et al., Bioorg Med. Chem. Lett., 10, 59-62 (2000).

17) Arjun, B., Yasuhiro, T. \& Shigetoshi, K., Phytother. Res., 15, 561-71 (2001). 